\title{
Identified Characters, Dialogue of Ethnicity in Indonesia Animated Film
}

\author{
Yully Ambarsih \\ Art and Design Study Program \\ Institut Teknologi Bandung \\ Bandung, Indonesia \\ yullyambarsih@student.itb.ac.id \\ Irfansyah \\ Art and Design Study Program \\ Institut Teknologi Bandung \\ Bandung, Indonesia
}

\author{
Imam Santosa \\ Art and Design Study Program \\ Institut Teknologi Bandung \\ Bandung, Indonesia
}

\author{
Hafiz Azis Ahmad \\ Art and Design Study Program \\ Institut Teknologi Bandung \\ Bandung, Indonesia
}

\begin{abstract}
Diversity in animated film shows clearly in the film Adit Sopo Jarwo. It will show how an inter-ethnic group relates to each other. This film has the desire to demonstrate equality through the interaction of the characters. In these characters, the public features are clearly shown, through their ethnic character. The relation between characters indicates the existence of classification or stereotype wrapped in the issue of ethnicity, and packed with a humorous approach. Some ethnic characters seen as a disturber, while other figures from other ethnic groups are mediators. The role is not separated from the cultural influences brought by the ethnic. In this case, the situation is depicted in the animated film into a case study. Ethnicity is an issue in the form of describing the situation and the interaction between the characters. The deepening of the animated film Adit Sopo Jarwo in the context of the cultural system will complement the direction of Indonesian animated film making.
\end{abstract} Jarwo

Keywords-character, ethnicity, animated film, Adit Sopo

\section{INTRODUCTION}

Indonesia has made some animated films, one of them is Adit Sopo Jarwo, in which shows diversity through the characters. Those has a role in the film, and become a presentation of the social role. Diversity was expressed by presenting figures from various ethnic groups in Indonesia, such as Javanese, Betawi, Sundanese and Chinese. Interestingly the presence of certain ethnic is positioned in the context of social roles in the film. This role refers to the stereotypes that are recognized by the community. These characters in this film build identity, based on the concept of diversity in Indonesia. Dialogue of characters refer to relation between them in the film. Certain ethnic groups are described as having a marginal position, but in the context of this film it is different. So this paper emphasizes the concept of inter-tribal dialogue, to show the existence of special social roles.

Animated film studies that become a foothold refers to two characteristics, that is, studies that can be a comparison, and the others become references. Research on the world of animation by Luca Raffaelli is a perspective on the development of animated films in America and Japan. Specifically shows how people's attitudes and perspectives are represented through animated films[1]. Highlighting this, it becomes a common practice if animated films made in Indonesia are a representation of Indonesian society as well. Born refers to Confucian values in Japanese animated films, how film can be a medium for understanding these values. The Confucian concept is shown through the level of structure between characters, and how the characters face their respective problems. Adit Sopo Jarwo's film shows diversity, through its characters from different ethnic groups. The film shows relationships between characters based on social roles in the film. In addition to togetherness, there were also conflicts that occurred between several figures. This shows that the problem of ethnicity remains an object that cannot be separated from the facts of the Indonesian people. The extent of the land, the number of ethnic groups inhabiting the islands, and the distribution of these ethnic groups have become a separate issue in society[2].

Basis studies comes from Pedersen regarding figures made with CGI animation techniques (computer generated imagery), that can be made to closely resemble the reference. The impression displayed is three-dimensional (3D)[3]. These figures need to be supported by believability through certain aspects, including appearance, personality, intentionality, emotions and social relations. It is not just about the level of resemblance, but there are forces that give the impression of life in it. Similar to Pedersen is Maldonado and Hayes-Roth research on believability based on cultural approaches)[4]. Culture is broken down in elements that 
influence a person's behavior and actions. Referring to previous studies, this paper emphasizes the elements of ethnicity displayed in the film Adit Sopo Jarwo. Believability is also seen from the five-factor theory or the big five, a characterization approach based on his personality. Reference [5] stated there are five personality dimensions related to the nature and attitude of the self, and attitudes towards others.

\begin{tabular}{|l|l|l|}
\hline \multicolumn{2}{|c|}{ THE BIG FIVE THEORY } \\
\hline Dimensions & Referencss & $\begin{array}{l}\text { Lowest } \\
\text { Conditions }\end{array}$ \\
\hline Openness & $\begin{array}{l}\text { Imaginative, } \\
\text { more varied in } \\
\text { choosing, } \\
\text { independent, } \\
\text { intellectually } \\
\text { sensitive }\end{array}$ & $\begin{array}{l}\text { Humble, } \\
\text { conventional, } \\
\text { easy to adapt, } \\
\text { low aesthetic } \\
\text { appreciation }\end{array}$ \\
\hline $\begin{array}{l}\text { Conscientiousn } \\
\text { ess }\end{array}$ & $\begin{array}{l}\text { Well organized, } \\
\text { careful, reliable, } \\
\text { self-discipline, } \\
\text { consistent }\end{array}$ & $\begin{array}{l}\text { Irregular, } \\
\text { careless, } \\
\text { weak-willed, } \\
\text { aimless }\end{array}$ \\
\hline
\end{tabular}

Table continue

\begin{tabular}{|l|l|l|}
\hline Extraversion & $\begin{array}{l}\text { Associate, } \\
\text { warm, } \\
\text { affectionate, } \\
\text { optimistic, } \\
\text { active }\end{array}$ & $\begin{array}{l}\text { Quiet, } \\
\text { drunk, } \\
\text { withdrawn }\end{array}$ \\
\hline Agreeableness & $\begin{array}{l}\text { Trustworthy, } \\
\text { helpful, gentle, } \\
\text { humble }\end{array}$ & $\begin{array}{l}\text { Suspicious, } \\
\text { cynical, cruel, } \\
\text { uncooperative }\end{array}$ \\
\hline Neuroticism & $\begin{array}{l}\text { Anxious, has } \\
\text { experience with } \\
\text { negative } \\
\text { emotions, is } \\
\text { vulnerable, easy } \\
\text { to } \\
\text { impulsive worry, }\end{array}$ & $\begin{array}{l}\text { Safe, calm, } \\
\text { easily } \\
\text { complacent }\end{array}$ \\
\hline
\end{tabular}

Characters in Adit Sopo Jarwo interact with each other based on their social roles, namely Jarwo from Java, Adit and Haji Udin representing Betawi, and Baba Chang representing Chinese. Ethnic group is an ascriptive social group that has a number of characteristics, first, ethnicity is a unit of life that is biologically capable of breeding; secondly, every ethnic group has a culture and institutions that serve as guidelines for their lives; and thirdly, membership in ethnic groups is ascriptive, meaning that membership is related to the area of origin, and the family that gave birth to it [6]. The presence of ethnic groups in one area will bring social interaction, even though there are identities that are not displayed in full, in the sense that there is a selection of the attributes displayed. Syafri explained Moermann's ideas which states that the attributes raised in the disclosure of ethnicity are influenced by situations where interaction between ethnic groups takes place[6].
There are two kinds of ethnicity attributes that are displayed in the interaction between different people, first, the signs or characteristics that are open, or which can be seen or observed directly. Second, that which is closed, or which cannot be observed, such as a fundamental value orientation and moral standards[6].

When this is a grouped reference, it will become ethical and moral values, or worldview (ideal or what should be) along with ethos, or actual values. This context refers to the culture of each ethnic group. So culture serves as a reference for interpretation in realizing social action. Furthermore, it is understood as an encouragement / motivation that develops in an individual, as well as a person's response to various things they face[6]. Culture serves as a guide for operational life through the classification of the roles that apply to the lives of citizens. This is a categorization system that serves to sort out the smallest elements in culture by using guidelines that exist in religious, moral, and cosmological values.

\section{METHOD}

Studying characters in this film is carried out in three stages, namely: (1) determine the character under study, (2) examine based on visible aspects, by studying the way of dress and accentuation when speaking, (3) relations or relationships between characters based on ethnicity and values adhered to it.

\section{RESULTS}

Ethnicity in this film is a presentation of Indonesian society, deeper shows the ideal view of inter-ethnic relations. In reality inter-ethnic/ethnic relations are understood as stereotypes, that is comfortable for the people. Iin this film shows more equality. Stereotype determination is emphasized only on visual and dialect elements, but not on its social role. there is a moral value that wants to be more visible for the audiences.

\section{DISCUSSION}

The figures are as follows:

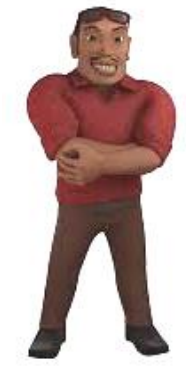

Fig. 1. Jarwo is Javanese 


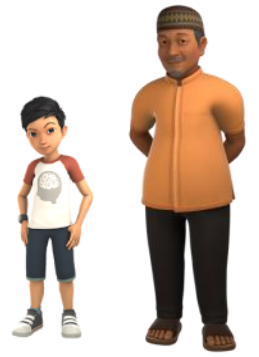

Fig 2. Adit dan Haji Udin are Betawi

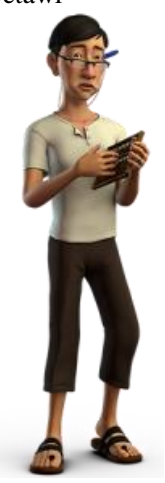

Fig 3. Baba Chang is Chinese

The position of each character in the film is Jarwo (fig.1) and Adit (fig. 2) as the main characters, Haji Udin (fig.2) and Baba Chang (fig.3) are supporting figures. Jarwo as the main character is shown from the lower class. Adit also as the main character is shown from upper class if compared to Jarwo. So this characters is determined based on the following criteria:

a. Derived from certain ethnic groups to represent diversity

b. Visually show certain stereotypes

c. Having relationships between characters based on social roles in the film

Diversity in the context of nationality is a fact of the Indonesian state. Having more than 400 tribes, it is common if the level of diversity is very high. To date there are tribes that are in a dominant position, mainly because they live in urban centers, one of which is Javanese. While the country's capital city is Jakarta, which is located on the island of Java. So it becomes a common practice if there are people from Javanese tribes living in the city of Jakarta and associating with the Betawi tribe (which is an indigenous tribe in Jakarta).

In the film Adit Sopo Jarwo, Jarwo as the main character is shown to come from Java. Explicitly visible through accent or how to speak. The other main character is Adit who is shown as a 10-year-old child who has a brave, active nature, and is able to motivate friends or people in the surrounding environment. Supporting figures in this film are Haji Udin who is also portrayed as a Betawi indigenous tribe, can be seen from the accent or the way he speaks. The second supporting figure is Baba Chang, who is an ethnic Chinese. Ethnic Chinese is one of the tribes that are often featured in films in Indonesia, with certain characteristics especially as a trader.

The characters in this film are shown visually, through certain stereotypes. The term raised by Lippman states that the stereotype is an image on the head which is a reconstruction of the actual environmental conditions. In other words, stereotypes are one of the simplest mechanisms to control the environment, because the actual environment is too broad, too diverse, and moves too quickly to be recognized immediately. This description of the state of the environment determines what someone does. This has an impact on how a person understands a situation, which is not based on direct recognition of the actual state of the environment, but based on an image made by himself or given to him by others.

The following is how the characters in the film Adit Sopo Jarwo are shown based on stereotypes:

CHARACTERS, PERSONALITY AND VISUAL ATTRIBUTES

\begin{tabular}{|c|c|c|c|}
\hline No & Name & Personality & $\begin{array}{c}\text { Visual } \\
\text { Attributes }\end{array}$ \\
\hline 1 & Jarwo & $\begin{array}{l}\text { Agreeableness } \\
\text { Positive } \\
\text { dimension: } \\
\text { Can be trusted } \\
\text { helpful } \\
\text { soft heart } \\
\text { Negative } \\
\text { dimension: } \\
\text { Suspects } \\
\text { cynical } \\
\text { cruel } \\
\text { not } \\
\text { cooperative }\end{array}$ & $\begin{array}{l}\text { Long pants, } \\
\text { cotton fabric and } \\
\text { leather shoes } \\
\text { Sunglasses }\end{array}$ \\
\hline 2 & Adit & $\begin{array}{l}\text { Openness } \\
\text { Positive } \\
\text { dimension: } \\
\text { Imaginative } \\
\text { more varied in } \\
\text { choosing } \\
\text { independent } \\
\text { intellectually } \\
\text { sensitive } \\
\text { Negative } \\
\text { dimension: } \\
\text { humble } \\
\text { conventional } \\
\text { easy to adjust } \\
\text { low esthetic } \\
\text { appreciation }\end{array}$ & $\begin{array}{l}\text { White shirt with } \\
\text { red sleeves } \\
\text { A silhouette of } \\
\text { the head and } \\
\text { brain that looks } \\
\text { transparent }\end{array}$ \\
\hline & & & $\begin{array}{l}\text { Knee-length } \\
\text { jeans } \\
\text { Shoes } \\
\text { Wristwatch }\end{array}$ \\
\hline
\end{tabular}




\begin{tabular}{|l|l|l|l|}
\hline 3 & $\begin{array}{l}\text { Haji } \\
\text { Udin }\end{array}$ & $\begin{array}{l}\text { Agreeableness } \\
\text { Positive } \\
\text { dimension: } \\
\text { Can be trusted } \\
\text { helpful } \\
\text { soft heart } \\
\text { Negative } \\
\text { dimension: } \\
\text { Suspects } \\
\text { cynical } \\
\text { cruel } \\
\text { not } \\
\text { cooperative }\end{array}$ & $\begin{array}{l}\text { Koku clothes } \\
\text { Cotton slacks } \\
\text { Leather sandals }\end{array}$ \\
\hline Baba & $\begin{array}{l}\text { Neuroticism } \\
\text { Positive } \\
\text { dimension: } \\
\text { Anxious, has } \\
\text { experience } \\
\text { with negative } \\
\text { emotions, } \\
\text { vulnerable, } \\
\text { easy to worry, } \\
\text { impulsive }\end{array}$ \\
$\begin{array}{l}\text { Negative } \\
\text { dimension: } \\
\text { Safe, calm, } \\
\text { easily } \\
\text { complacent }\end{array}$ & $\begin{array}{l}\text { White T-shirt } \\
\text { Eyeglasses } \\
\text { Pants brown } \\
\text { Leather sandals }\end{array}$ \\
\hline
\end{tabular}

Table 1 shows the visualization of the characters and their attributes. The stereotype here refers to the concept of role in film. The main character consists of Adit and Jarwo. If observed visually, there is no special feature, in the form of a symbol. In other words visually, the main characters are not placed to be interpreted specifically. Attributes such as shirts, jeans, shirts, shoes or sandals are used to show that the characters are members of ordinary society.

In supporting figures there are more specific characteristics. Like Haji Udin who was shown using koko and skullcap, and Baba Cang used a T- shirt with pants. Visual stereotypes like this are commonly shown on other media.

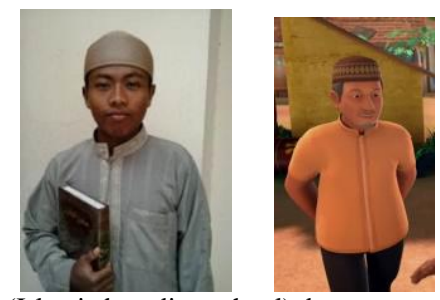

Fig 4. The way santri (Islamic boarding school) dress
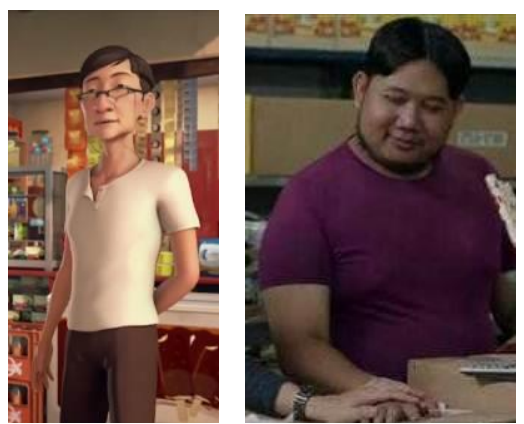

Fig. 5. Chinese shop owner

Other stereotypes are shown through accent or expressions through voices, such as:

Jarwo often says the word "halah" or "mbok kamu tu...". These two are Javanese saying for emphasizing situations. Or, when Baba Cang says, "Jalwo, Oe puciang haia ...". The word "oe" means "I", and only Chinese people in Indonesia use that word. The other is "haia", is an expression for certain situation. Only the Chinese in Indonesia use it. Nowadays, even younger generation of Chinese never use it again.

This shows that visual expressions emphasize more on general concepts that are easily recognized by the audience. The aim is to facilitate the audience's understanding of the social role between the characters. The relationship between the four characters in this film can be seen as follows:

Jarwo is Javanese, works for Baba Cang, who is Chinese. Jarwo is Haji Udin's brother-in-law who is a native of Jakarta, namely the Betawi. Jarwo often helps Adit's mother, who is also a Betawi tribe. Adit also often helps Baba Cang at certain times. Haji Udin and Baba Cang were friends since childhood.

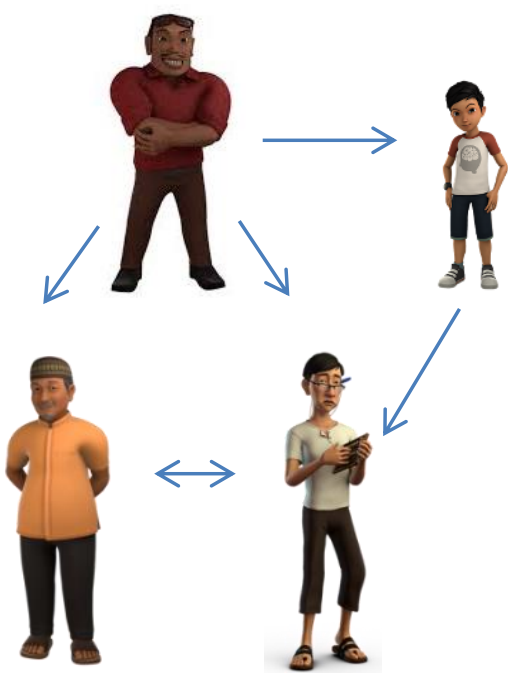

Fig. 6 Relationship between characters

Three of the four figures are shown to come from different ethnic groups. Ethnicity itself is a form of social boundary to make criteria for identifying its membership. Suparlan's explanation in Syafri stated that culture inherent in ethnic groups is a person's motivation and its response to various things it faces [6]. The placement of ethnic groups in stereotyped characters is like being placed in a certain position. The picture is as follows: Jarwo a Javanese works 
with Baba Cang who is Chinese. Jarwo also likes to accept work from Adit's mother, who is a Betawian. Jarwo was placed as a worker, lower than Baba Cang and Adit. However, Jarwo is Haji Udin's brother-in-law who is a friend of Baba Cang. Jarwo has the same position as Haji Udin. And this puts Jarwo in a position equivalent to Baba Cang. Besides that, Adit was also shown to often help Baba Cang, so Adit and Jarwo became equals.

This film wants to show that ethnicity creates boundaries, supported by stereotypes, then there will be images that show a multilevel position. However, Adit Sopo Jarwo's film looks at ethnic groups in the present context, when the boundary has mingled with the agreed values of morality.

\section{CONCLUSION}

Ethnicity remains an idea that is worked on continuously, because it is always found new form in looking at the position or social role in it. Adit Sopo Jarwo's film shows that stereotyping is not something that is binding, especially in the context of ethnicity. There is a greater moral value in showing how characters can dialogue with each other.

\section{ACKNOWLEDGMENT}

Our gratitude are given to the DKV UNIKOM Study Program and UNIKOM as supporters of the implementation of this study. Also given to the Bandung Institute of Technology Art and Design Doctoral Program, as a place of study, which has a role in guiding, directing research.
Specifically submitted to:

1. Dr. Imam Santosa, M. Sn., Dr. Hafiz Azis Ahmad, M. Des. and Dr. Irfansyah, M. Sn. as a mentor who gives direction on how to write this paper.

2. Assoc. Prof. Dr. Eddy Suryanto Soegoto, M. Si. which always encourages and supports the implementation of further studies.

\section{REFERENCES}

[1] Raffaelli, L. Disney, Warner Bros. And Japanese Animation Three world Views. A Reader in Animation Studies. Lancaster: John Libbey Publishing Ltd. 2011, p 112-136

[2] Born, C.A. In The Footsteps of The Master: Confisian Values in Anime and Manga. 2009.

[3] Pedersen, L. B. A Study in Perceived Believability Utilizing Visual Movement To Alter The Level Of Detail. Copenhagen: Aalborg University. 2013

[4] Maldonado, H., Hayes-Roth, B. Toward Cross-Cultural Believability in Character Design. In Agent Culture Human-agent Interaction in A Multicultural World. London: Lawrence Elbaum Associates Publishers. 2004

[5] Big Five Personality Traits \& The 5-Factor Model Explained [+PDF] tersedia di https://positivepsychologyprogram.com/big-fivepersonality-theory/ (15/05/2018)

[6] Syafri, Y. Kontekstualisasi Kesukubangsaan di Perkotaan. Tanpa kota: Institut Antropologi Indonesia (IAI). 2010 